\title{
Development of creativity of a future teacher as a condition for their effective work with gifted students
}

\author{
Nadezhda Anatolievna Shaidenko ${ }^{1 *}$, Svetlana Nikolaevna Kipurova ${ }^{1}$, Aleksandra \\ Vladimirovna Sergeeva ${ }^{2}$, Maria Vyacheslavovna Filatova ${ }^{3}$, and Ellada Vladimirovna \\ Shelispanskaya ${ }^{4}$ \\ ${ }^{1}$ The Advanced Training and Professional Retraining Institute of Education Professionals of Tula \\ Region, Center for the Strategic Planning of the Education Development, Expertise and Scientific \\ Advice, Tula, Russia \\ ${ }^{2}$ Tolstoy Tula State Pedagogical University, Faculty of Technology and Business, Department of \\ Economics and Management, Tula, Russia \\ ${ }^{3}$ The Advanced Training and Professional Retraining Institute of Education Professionals of Tula \\ Region, Department of Preschool and Primary General Education, Tula, Russia \\ ${ }^{4}$ Tolstoy Tula State Pedagogical University, Faculty of Psychology, Department of Psychology and \\ Pedagogy, Tula, Russia
}

\begin{abstract}
Work with gifted students requires a teacher to have special personal and professionally important qualities and creativity occupies a special place among them. A creative teacher can understand the peculiarities of behavior and worldview of a gifted child and possesses the competencies of organizing further development of the creative activity of special children, as well as their relationships with peers. The study is based on the concepts of axiological, humanistic, systemic, and activity approaches, the theory of convergent and divergent thinking, the teachings of an individual as a person and subject, of creativity as a process and a result, the creative nature of a teacher's work, and theories addressing the creative essence of personality. The stage of university training is deliberately chosen for the study of the problem of development of a teacher's creativity as a foundation for work with gifted students since the student age is the most sensitive period of this process. In the process of higher education, the development of a future teacher's creativity in conjunction with their professional and personal qualities is essential as a condition for effective work with gifted students. The identified key psychological and pedagogical conditions for the development of creativity in professional activity focused on work with gifted students include the professional activity orientation of future teachers to work with gifted children, professional knowledge, skills, and competencies focusing on gifted children, and psychological qualities of professional importance for work with gifted students. The article provides a specified definition of creativity, characterizes the signs of a teacher's creativity, and describes the patterns, conditions, and stages of development of a future teacher's creativity in the educational process in a higher education institution. The
\end{abstract}

* Corresponding author: nashaidenko@gmail.com 
directions for further scientific theoretical and practical activities in the process of development of a future teacher's creativity in parallel with training to work with gifted children are proposed. A promising direction of work is determining the ways to combine the operational and substantive sides of a teacher's activity in work with gifted children.

Keywords: creativity; creative activity; gifted students; future teacher; educational process.

\section{Introduction}

The most important condition for the sustainable development of civilization is a change in the activity of a teacher, their professional and personal qualities. Society wants to see a teacher of the 21st century as a creative professional who is ready for continuous creative development, has a humanistic attitude, and is capable of creative organization of interaction with other subjects of education.

Gifted children form a special group of students. Their number and the variety of types of giftedness are constantly increasing nowadays, therefore, a teacher has to develop special competencies to work with such children [1]. In addition, only a creative teacher can understand gifted children and be able to work with them effectively [2]. This outlines the problem of our study: the question of how to form a teacher's creativity that presents a condition for effective work with gifted students.

\section{Methods}

The methodological basis of the study is formed by the concepts of axiological, humanistic, and systemic and activity approaches, the theory of convergent and divergent thinking [3], the teachings of an individual as a person and subject, of creativity as a process and a result, the creative nature of a teacher's work, and theories addressing the creative essence of personality [4], its creative characteristics, the creative nature of teaching, the processes of teacher training, etc.

The deployed scientific research methods include the study of philosophical, psychological, and pedagogical literature on the problem, the study of the experience of creatively working teachers, the methods assessing the level of development of personality creativity and providing a quantitative result, as well as the methods of pedagogical correction [5].

\section{Results}

The main ideas behind our study are the assertion of the dynamic nature and integrative structure of creativity and the need to implement humanistic, person-centered, and competence-based approaches in the process of creativity development.

Systematic research of the category of creativity has been conducted since the beginning of the 1950s. More than sixty definitions of the concept of "creativity" were substantiated and work on them continues which leads to the emergence of various, often opposite theories. Nowadays, creativity remains a controversial and insufficiently studied phenomenon in psychology $[6,7]$.

In summary, we provide a brief identification of the main features of creativity:

- creativity is the ability to adequately respond to the inevitability of new approaches and phenomena and adapt to changes in the external environment; 
- the characteristic properties of the creative process of a creative person and its result (product) include independence, adequacy, originality, and validity;

- the objects of influence that results in a creative product can be different ranging from the resolution of social issues to the creation of a new musical (literary, visual) work, from the proof of a mathematical theory to the construction of a new religious theory [8].

Scientific research examines and describes the main approaches to creativity in Russian and foreign pedagogy and psychology, expands and refines the views on the creativity of a teacher, identifies and scientifically validates the trends, principles, technologies, content, and conditions for the effectiveness and development of future teachers' creativity in the educational process of higher education including the groups of didactic, social and organizational, and psychological and pedagogical conditions [9].

What we consider the main psychological and pedagogical conditions for the development of creativity in professional activity focused on work with gifted students is the professional activity orientation of future teachers to work with gifted children, their professional knowledge, skills, and competencies that focus on gifted children, and psychological qualities of professional importance for work with gifted students [10].

The creativity of future teachers can be considered in a narrow and broad sense.

In a broad sense, creativity manifests as the use of a familiar method of work with children in the form of improvisation in the changed conditions, the modernization of familiar technologies in accordance with the new content of education and new tasks, the choice of the best option in addressing the given pedagogical situation, improvisation leading to the best result, and rethinking and revision of the proposed recommendations, scientific ideas, and provisions [11].

In a narrow sense, creativity refers to innovation as the discovery of innovation for oneself and others, the identification and formulation of fundamentally new patterns of work with gifted children, and the development of original approaches, methods, and techniques for work with gifted children that change the existing views and work experience [12].

\section{Discussion}

In the numerous requirements for the modern teacher, special importance is attributed to their personal and professionally important qualities, among which creativity occupies an increasingly prominent place [13].

We view the creativity of a teacher as a personality characteristic that reflects its sensitivity to the new, as well as the desire and ability to quickly find and logically apply creative solutions to pedagogical situations in professional activity.

Non-standard situations can occur for different reasons including the psychophysiological characteristics of students. Gifted children comprise a special group of students, successful work with which requires a teacher to have well-developed creativity. This substantiates the need to develop the creativity of future teachers in the process of university training [14].

The organization of work on the development of students' creativity must account for the patterns of this process: the contingency of creativity on the social, political, and economic changes occurring in a society; the effectiveness of the process being conditioned by the presence of the necessary social, organizational and technical and pedagogical conditions in the university; the purposeful work of university teachers on the development of future teachers' creativity; the correspondence of the forms, methods, and technologies of work to basic components of creativity [15].

What can be considered the fundamental principles of the characterized process are the principle of humanization of teacher training in higher education, the principle of integrity, the principle of interdisciplinary integration, and the principle of modeling. 
The formation and development of future teachers' creativity have to go through several stages: providing the corresponding conditions in the educational environment of a university; selecting special technologies of creative expression for the activation of students' creative potential of students and incorporating them into the educational process; analyzing and addressing the problems and blockages in creative activity; development and consolidation of creative skills and competencies.

The use of the personality-centered approach implies the formation of an adequate understanding of their personality and real and possible creative abilities in future teachers, the maximum disclosure of individual creative traits of students as future teachers, the development of creativity simultaneously with other professional personal qualities, the formation of future teachers' competence in promoting the development of creativity in their students, the development of students' skills in recognizing and using their personal characteristics and abilities in creativity [16].

The activity approach to training teachers for work with gifted students implies future teachers studying the essence, content, and peculiarities of this group of students, the specifics of creative professional work with them, the introduction of a creative component in teaching all types of academic disciplines in higher education, the use of innovative methods in developing students' creative professional competencies, and the active utilization of creative quasi-professional tasks in the educational process.

It is expedient to distinguish the following levels of development of students' creativity:

The reproductive level, at which students' pedagogical needs are poorly expressed and motivation is impoverished. The achievement motive is often replaced with the motive of expectation of success. A future teacher unaware of the goal of the forthcoming activity, therefore, it is not attractive for them. A student does not demonstrate readiness for selfdevelopment and reflexive activity. Their self-assessment of their creativity level is often overestimated. Knowledge in the sphere of professional and pedagogical activity is superficial and not operational. Pedagogical competencies are not focused on creative examples. Creative activity manifests sporadically.

The constructive level which can be considered sufficient and necessary is characterized by a more interested attitude towards professional activity and knowledge about creativity and gifted children. Professional needs prevail. The interest in creative solutions to professional problems is occasionally observed. Self-assessment of the level of one's creativity approaches adequacy. Competences in work with gifted students are sufficiently flexible. Creativity in activity is selective.

The creative level is characterized by a high level of creativity development. The knowledge of creativity is consolidated consciously with a positive emotional attitude. The need for self-development of creativity and the implementation of creative activities with gifted students is stable [17].

\section{Conclusion}

The conducted study allows for the following conclusions:

- only a creative teacher can optimally organize the education of a gifted student, thus, the problem of developing the creativity of future teachers is relevant;

- the development of creativity components, particularly competencies in work with gifted schoolchildren, implies the following directions of improvement of professional training of teachers: achieving complete readiness, i.e. preparation for performing all professional-pedagogical functions, the integrity of this readiness. Work with gifted children is gaining increased importance among these professional functions.

Analysis of the quality of training of young teachers [18] shows that the obtained knowledge and developed practical skills are not always used by graduates creatively. 
Students' readiness for the development of their creativity combines the interrelated attitudes towards the upcoming professional activity, the process of teaching, and towards themselves, and the development of these attitudes has to be addressed in higher education.

Thus, in the process of higher education preparation of the future teacher, it is necessary to develop their creativity in addition to other professional and personal qualities as a necessary condition for effective work with gifted students.

The problem of training teachers to work with gifted children in the process of developing their creativity is complex and multifaceted, therefore, it is not resolved completely within the framework of the conducted study. The proposed directions for further scientific and theoretical and practical activities include:

- the expansion of psychological and didactic conclusions on the development of creativity in future teachers;

- clarification of teachers' competencies in work with gifted children and the search for optimal technologies for their development;

- identifying the ways to combine the operational and content aspects of a teacher's activity in working with gifted children.

\section{Acknowledgments}

The article was supported by the Russian Foundation for Basic Research and the Government of the Tula Region, research project No. 19-413-710005 p_a "Methodology for the study of professional difficulties of young teachers and the development of mechanisms for overcoming them (on the example of the educational space of the Tula region)".

\section{References}

1. S.V. Demanova, D.E. Demanova, Izvestiya of Saratov University. Economics. Management. Law, 1, 81-88 (2020). https://doi.org/10.18500/1994-2540-2020-20-1$81-88$

2. V. A. Mazilov, Iu.N. Slepko, ITS, 3(100), 412-432 (2020). https://doi.org/10.15507/1991-9468.100.024.202003.412-432

3. V.L. Krainik, R.T. Diianova, Mir Nauki, Kultury, Obrazovaniia, 3(76), 333-335 (2019)

4. M.-J. Sánchez-Ruiz, B. Carducci, C. Nave, A. Fabio, D. Saklofske, C. Stough, Creativity, 11, 89-93 (2020). https://doi.org/10.1002/9781118970843.ch192

5. E.I. Shcheblanova, Theoretical and Experimental Psychology, 4, 38-53 (2018)

6. J. Rošker, Asian Studies, 8, 141-160 (2020). https://doi.org/10.4312/as.2020.8.3.141160

7. V.P. Glăveanu, R. Beghetto, Creativity Research Journal, 33(2), 75-80 (2021). https://doi.org/10.1080/10400419.2020.1827606.

8. O.A. Khalifaeva, Siberian Journal of Psychology, 69, 172-190 (2018). $10.17223 / 17267080 / 69 / 10$

9. V. Intagliata, R. Scharf, Pediatrics in Review, 38, 575-577 (2017). https://doi.org/10.1542/pir.2017-0088

10. N.V. Iaroslavtseva, A.A. Beliakov, B.T. Tukhvatullin, A.Ch. Kodoeva, V.R. Nigamatulin, D.V. Levchenko, A.N.Dakhin, Psychological-Educational Studies, 1(43), 10-23 (2020). https://doi.org/10.32744/pse.2020.1.1 
11. N. A. Shaidenko, V. G. Podzolkov, A. N. Sergeev, S. N. Kipurova, A. V. Sergeeva, Metodicheskie rekomendatsii dlia rabotnikov obrazovatelnykh organizatsii po praktike primeneniia osnovnykh polozhenii Federalnogo Zakona No. 273-FZ ot 29 dekabria 2012 g. "Ob obrazovanii v Rossiiskoi Federatsii" reglamentiruiushchikh prava i obiazannosti uchastnikov obrazovatelnykh pravootnoshenii: ucheb.-metod. posobie [Methodological recommendations for employees of educational organizations on the practical application of the main provisions of the Federal Law No 273-FZ of December 29, 2012, "On Education in the Russian Federation" regulating the rights and obligations of participants in legal educational relations: educational and methodological manual] (Tula State University Publishing House, Tula, 2016)

12. C. Burt, British Journal of Statistical Psychology, 14, 123-139 (2011). https://doi.org/10.1111/j.2044-8317.1961.tb00074.x

13. Z.D. Rasulova, European Science, 2-2(51), 65-68 (2020)

14. A.A. Baranov, A.S. Suntsova, The Education and Science Journal, 2, 29-52 (2020). https://doi.org/10.17853/1994-5639-2020-2-29-52

15. O.V. Kisel, A.I. Dubskikh, A.V. Butova, Higher Education in Russia, 8-9, 95-103 (2020). https://doi.org/10.31992/0869-3617-2020-29-8-9-95-103

16. E.G. Beliakova, I.G. Zakharova, The Education and Science Journal, 1, 84-112 (2020). https://doi.org/10.17853/1994-5639-2020-1-84-112

17. L.N. Makarova, S.V. Rozhkova, Tomsk State University Journal, 179, 7-19 (2019). https://doi.org/10.20310/1810-0201-2019-24-179-7-19

18. N.A. Shaidenko, Pedagogika, 6, 65-73 (2014) 